$$
\begin{array}{cccc}
\text { S sciendo } & \text { International Conference KNOWLEDGE-BASED ORGANIZATION } \\
\text { Vol. XXV } & \text { No } 2 & 2019
\end{array}
$$

\title{
THE STATE OF NOMINAL CONVERGENCE IN ROMANIA IN THE CONTEXT OF JOINING THE EURO AREA
}

\author{
Cristina Maria BĂTUŞARU \\ "Nicolae Bălcescu" Land Forces Academy, Sibiu, Romania \\ batusaru.cristina@gmail.com
}

\begin{abstract}
The repeated postponement of the deadlines set for Romania's accession to the Eurozone as well as the challenges facing the nominal convergence criteria raised many questions among the European community regarding the competitiveness of the Romanian economy in relation to the economies of the European countries adopting the single currency. The present paper aims to present the current state of nominal convergence our country manages to achieve and to import compliance with these criteria by exemplifying the concept of optimal monetary areas. The adoption of the single currency must be achieved in the context of sustainable convergence that guarantees the minimization of costs caused by the renunciation of national monetary policy. To achieve this goal, the present paper presents the optimal context that Romania's shift to the single currency should take into account in order to maximize its benefits from the beginning of this irreversible process.
\end{abstract}

\section{Keywords: nominal convergence, real convergence, Eurozone, imbalances}

\section{Introduction}

Romania's accession to the eurozone is a bold and long-lasting project, given the challenges our country experiences in fulfilling the nominal convergence criteria, characterized by numerous transfer delays to the euro area in relation to the programmed targets.

Robert Mundell's approach to opt-in monetary zones (OMZ) [1] proposes a number of conditions / factors that can influence the costs and benefits associated with the adoption of a single currency.

Beyond the importance of achieving and maintaining the conditions of nominal convergence, which guarantee the macroeconomic stability of the economies of the countries that want to adopt a single currency, it is necessary to minimize the costs of such a move.
The main cost of adopting the single currency is represented by the effects of renouncing national monetary policy instruments, especially in terms of the exchange rate mechanism. Addressing this issue is a real challenge for the macroeconomic policy of a state since the need for exchange rate adjustment and monetary policy instruments have typically been the levers that have ensured some of the main nominal convergence criteria (intervening to ensure the main nominal convergence criteria).

In order to minimize the costs of giving up monetary policy independence, it is very important that the country in question also meets the real convergence criteria. The fulfillment of real convergence conditions is the premise of an advantageous monetary integration, as the economic aspects concerned ensure a high degree of openness 
of the economy, high labor mobility, price and wage flexibility, and a high degree of financial development which facilitate the reduction of development gaps, as compared to countries in the European model. Although the real convergence criteria are not strictly defined by the European Commission, given the specificities of each country, they are designed to reduce the costs of participation in the monetary union, provided that the nominal convergence criteria are met. Monetary integration is beneficial to participants and maximum benefits are achieved when convergence is assured.
2. The Performance of Romania in Meeting Nominal Convergence Criteria Romania's accession to the European Union opened up the prospects for the development of the national economy, but the accession moment was preceded by an unfavourable international economic context, characterized by the economic and financial crisis, which placed quite a lot of pressure on the economic policy makers. Meeting the convergence criteria assumed by our country by signing the Treaties with the European Commission is one of the main economic policy objectives. However, after more than 11 years since the accession, meeting the nominal convergence criteria continues to represent a challenge.

Table 1: The stage of nominal convergence in Romania during 2007-2020

\begin{tabular}{|l|c|c|c|c|c|c|c|c|c|c|c|c|c|c|}
\hline & 2007 & 2008 & 2009 & 2010 & 2011 & 2012 & 2013 & 2014 & 2015 & 2016 & 2017 & 2018 & $2019 *$ & $2020^{*}$ \\
\hline $\begin{array}{l}\text { Inflation } \\
\text { rate (\%) }\end{array}$ & 4.9 & 7.8 & 5.6 & 5.5 & 5.8 & 3.4 & 3.2 & 2.5 & -0.4 & -1.1 & 1.1 & 1.9 & 3 & 3.1 \\
\hline $\begin{array}{l}\text { Long-term } \\
\text { interest } \\
\text { rate (\%) }\end{array}$ & 7.1 & 7.7 & 9.7 & 7.6 & 7.3 & 6.7 & 5.4 & 5.3 & 2.7 & 3.3 & 4 & 4.1 & 4.2 & - \\
\hline $\begin{array}{l}\text { Fluctuation } \\
\text { of } \\
\text { exchange } \\
\text { rate } \\
\text { (lei/euro) }\end{array}$ & 5.4 & $\begin{array}{c}9.7 /- \\
14.6\end{array}$ & 15.1 & $\begin{array}{c}1.71 /- \\
14.3\end{array}$ & -0.6 & -5.2 & 0.9 & -1.9 & 0 & -1 & -1.7 & -1.9 & -0.4 & 0.8 \\
\hline $\begin{array}{l}\text { Budget } \\
\text { Deficit (\%) }\end{array}$ & -2.5 & -5.4 & -8.3 & -7.2 & -5.2 & -3 & -2.3 & -2.2 & -0.7 & -3 & -2.9 & -3.3 & -3.4 & -4.7 \\
\hline $\begin{array}{l}\text { Public debt } \\
\text { of of } \\
\text { GDP) }\end{array}$ & 12 & 12.4 & 21.9 & 29.8 & 34.2 & 37 & 37.6 & 39.2 & 37.8 & 37.3 & 35.2 & 34.1 & 35.9 & 38.2 \\
\hline
\end{tabular}

Source: European Commission

The first indicator of nominal convergence refers to the inflation rate which, during the analyzed period, recorded relatively large fluctuations ranging between $-1.7 \%$ and $8 \%$, registering an average of around $3.5 \%$. Given the projections of the National Bank for this indicator, I believe that the sustainability of medium-term inflation is difficult to guarantee. To prevent the continuous manifestations of such fluctuations leading to macroeconomic imbalances, it is necessary to intervene through appropriate policies that support the appreciation of the exchange rate.
In Romania, public debt complied with the Maastricht Treaty, with an increasing trend in the period under review. The 2012-2017 period represented a stability period with regard to the budget deficit level, which fell below the $3 \%$ of GDP target for this criterion. Beginning with 2018, the implementation of fiscal relaxation measures and the increase in public sector spending have led to exceeding the ceiling. The increase in the budget deficit will imply an upward trend of public debt in the period 2019-2020. Ensuring the sustainability of public finances is a particular component of long-term macroeconomic equilibrium. 
Therefore, the two mentioned nominal convergence criteria should be the main priorities for fiscal and budgetary reforms elaborated by economic policy makers.

Between 2009 and 2015, long-term interest rates in Romania recorded a declining trend, matching the value corresponding to the convergence criterion. During the following period, this indicator recorded an average of around $4 \%$, higher than the $3.2 \%$ benchmark for long-term interest rates.

If, for the criteria outlined above, Romania has made notable progress since joining the EU, participation in ERM II was not possible due to the fact that it could not prove that the nominal criteria have been fulfilled without using the exchange rate. The trading of the national currency was achieved under a flexible exchange rate regime with controlled float, with a relatively high level of volatility observed throughout the analyzed period.

By analyzing the results recorded among the nominal convergence indicators in the analyzed period, we can state that the information generated is insufficient and unpredictable when we refer to the medium and long term convergence sustainability. Consequently, meeting these criteria at present is not a guarantee that they will follow the same trend in the future, which is particularly important, especially since the decision to move to the euro area is also based on these indicators.

\section{The Importance of Economic Convergence in the Context of Optimal Monetary Areas}

If we also refer to the defining criteria for optimal monetary areas, of which, according to Frankel and Wei (1998), the most relevant are the degree of openness of the economy and the degree of correlation of business cycles, the informational value of the nominal convergence indicators is incomplete.

Furthermore, the negative effects of the 2008 economic crisis which affected the economies of the countries that were already members of the euro area (Greece, Spain and Portugal) drew attention to the importance of synchronizing national economies to the other economies of the member countries participating in the single market and whose economic activity fulfills the conditions of sustainable nominal convergence. The importance of increasing economic integration among countries adopting a single currency is underlined by the need to guarantee the European area and especially the euro area, by implementing mechanisms to combat the negative effects of asymmetric shocks that may occur. Measures to ensure the stability of the euro area are therefore among the priorities of the European Commission. The decision to renounce the independence of a state's monetary policy must balance the benefits and costs generated by this shift. As the costs of accepting unique currency are inevitable, and aim at obtaining higher benefits, the emphasis has been on increasing the degree of economic integration between Member States, so as to ensure a high degree of convergence of business cycles.

Economists Frankel and Rose have attempted to highlight this correlation between the business cycle and the degree of economic integrity [2], starting from the following hypotheses:

- if a group of countries belonging to an economic union (in this case the European Union) is in point 1, i.e. below the optimal currency area (OCA), it is advisable to maintain the independence of monetary policy;

- when these countries form a single market (characterized by the insurance of sustainable convergence) and have reached point 2 , they may decide to adopt the single currency, moving to point 3;

- the move to point 3 ensures a high degree of economic integration and the correlation of business cycles between these countries, highlighting the benefits of joining the monetary union. 


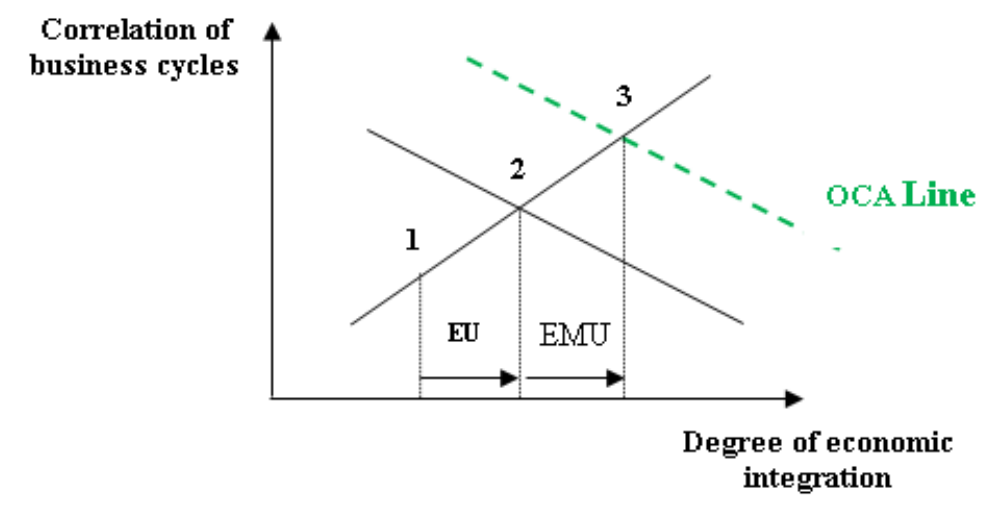

Figure 1: Stages of optimal economic integration between Member States

Considering the experiences of the economies of the states that have entered the eurozone too hastily, without proving a sustainable nominal convergence, it is necessary that the current candidate states taking the step towards adopting the currency introduce a monitoring and oversight algorithm to act as an earlywarning on the emergence of potential imbalances that would affect nominal convergence at national level. Thus, the
European Commission implemented the Macroeconomic Imbalance Procedure (MIP), based on a scoreboard of 14 indicators that analyze three categories of imbalances in the member states of the European Union [3].

The values recorded for the 14 indicators that are subject to Macroeconomic Imbalance Procedure for Romania are presented in the table below with reference to the years between 2010-2018.

Table 2MIP scoreboard indicators - Romania 2010-2018

\begin{tabular}{|c|c|c|c|c|c|c|c|c|c|c|c|c|}
\hline & Indicator & Unit & Limit & 2010 & 2011 & 2012 & 2013 & 2014 & 2015 & 2016 & 2017 & 2018 \\
\hline \multirow{5}{*}{ 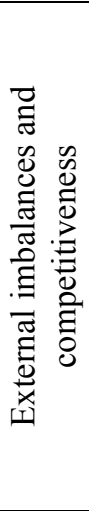 } & $\begin{array}{l}\text { Current account } \\
\text { balance - \% of } \\
\text { GDP }\end{array}$ & $\begin{array}{c}3 \text { year } \\
\text { average }\end{array}$ & $\begin{array}{l}-4 \% / \\
6 \%\end{array}$ & -7.2 & -4.9 & -4.9 & -3.6 & -2.2 & -1 & -1.3 & -2.2 & -3.3 \\
\hline & $\begin{array}{l}\text { Net international } \\
\text { investment } \\
\text { position }\end{array}$ & $\begin{array}{l}\% \text { of } \\
\text { GDP }\end{array}$ & $-35 \%$ & -63.4 & -65.4 & -67.4 & -62.6 & -57.3 & -51.9 & -49.9 & -47.7 & -44.7 \\
\hline & $\begin{array}{l}\text { Real effective } \\
\text { exchange rate - } 42 \\
\text { trading partners }\end{array}$ & $\begin{array}{c}3 \text { year } \\
\% \\
\text { change }\end{array}$ & $\pm 11 \%$ & -10.8 & -3.3 & -1.9 & 0.3 & -1.1 & 2.7 & -2.5 & -5.5 & -0.6 \\
\hline & $\begin{array}{l}\text { Export market } \\
\text { share - \% of } \\
\text { world exports }\end{array}$ & $\begin{array}{l}5 \text { year } \\
\% \\
\text { change }\end{array}$ & $-6 \%$ & 53.8 & 80.6 & 13.1 & 14.6 & 20.8 & 21.1 & 23.6 & 37 & 23.06 \\
\hline & $\begin{array}{c}\text { Nominal unit } \\
\text { labour cost index } \\
(2010=100)\end{array}$ & $\begin{array}{l}3 \text { year } \\
\% \\
\text { change }\end{array}$ & $12 \%$ & 28.8 & -0.5 & -0.2 & -3.2 & 7.3 & $0.5 \mathrm{p}$ & $6 p$ & $11.9 \mathrm{p}$ & $33.5 p$ \\
\hline \multirow{4}{*}{ 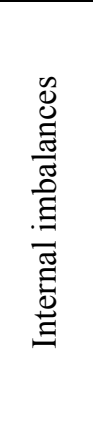 } & $\begin{array}{l}\text { House price index } \\
(2015=100)- \\
\text { deflated }\end{array}$ & $\begin{array}{c}1 \text { year } \\
\% \\
\text { change }\end{array}$ & $6 \%$ & -13.8 & -15.8 & -9.1 & -2.8 & -3.2 & 1.7 & 6.5 & 4 & 1.8 \\
\hline & $\begin{array}{c}\text { Private sector } \\
\text { credit flow - } \\
\text { consolidated } \\
\end{array}$ & $\begin{array}{l}\% \text { of } \\
\text { GDP }\end{array}$ & $14 \%$ & 0.9 & 2.8 & 0.3 & -1.4 & -2.4 & 0.2 & $0.6 p$ & $1.7 \mathrm{p}$ & $2.5 \mathrm{p}$ \\
\hline & $\begin{array}{c}\text { Private sector } \\
\text { debt - } \\
\text { consolidated } \\
\end{array}$ & $\begin{array}{l}\% \text { of } \\
\text { GDP }\end{array}$ & $133 \%$ & 73.9 & 72.9 & 17.9 & 66.6 & 62.1 & 59.1 & $55.8 \mathrm{p}$ & $\begin{array}{c}50.8 \\
\mathrm{p}\end{array}$ & $48.1 \mathrm{p}$ \\
\hline & $\begin{array}{c}\text { General } \\
\text { government gross } \\
\text { debt }\end{array}$ & $\begin{array}{l}\% \text { of } \\
\text { GDP }\end{array}$ & $60 \%$ & 29.9 & 34.2 & 37.3 & 37.8 & 39.4 & 37.9 & 37.6 & 35.1 & 35 \\
\hline
\end{tabular}




\begin{tabular}{|c|c|c|c|c|c|c|c|c|c|c|c|c|}
\hline & $\begin{array}{l}\text { Unemployment } \\
\text { rate }\end{array}$ & $\begin{array}{l}3 \text { year } \\
\text { average }\end{array}$ & $10 \%$ & 6.4 & 6.9 & 7 & 7 & 6.9 & 6.9 & 6.5 & 5.9 & 5 \\
\hline & $\begin{array}{c}\text { Total financial } \\
\text { sector liabilities - } \\
\text { non-consolidated }\end{array}$ & $\begin{array}{l}1 \text { year } \\
\% \\
\text { change }\end{array}$ & $\begin{array}{l}16,5 \\
\%\end{array}$ & 5 & 4.6 & 4.4 & 0.8 & 1.2 & 4.1 & 7.6 & 8.1 & $2.6 \mathrm{p}$ \\
\hline \multirow{3}{*}{ 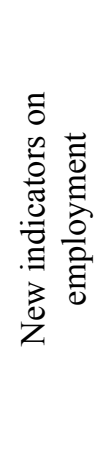 } & $\begin{array}{l}\text { Activity rate - \% } \\
\text { of total population } \\
\text { aged 15-64 }\end{array}$ & $\begin{array}{l}3 \text { year } \\
\text { change } \\
\text { in p.p }\end{array}$ & $-0,2 \%$ & 1.9 & 1.2 & 1.7 & 0 & 1.6 & 1.3 & 0.7 & 1.6 & 1.7 \\
\hline & $\begin{array}{c}\text { Long term } \\
\text { unemployment } \\
\text { rate - } \% \text { of active } \\
\text { population aged } \\
15-74\end{array}$ & $\begin{array}{l}3 \text { year } \\
\text { change } \\
\text { in p.p }\end{array}$ & $0,5 \%$ & -0.8 & 0.5 & 0.8 & 0.8 & 0.1 & 0 & -0.2 & -0.8 & -1.2 \\
\hline & $\begin{array}{c}\text { Youth } \\
\text { unemployment } \\
\text { rate - \% of active } \\
\text { population aged } \\
15-24 \\
\end{array}$ & $\begin{array}{l}3 \text { year } \\
\text { change } \\
\text { in p.p }\end{array}$ & $2 \%$ & 2.8 & 6.3 & 2.6 & 1.6 & 0.1 & -0.9 & -3.1 & -5.7 & -5.5 \\
\hline
\end{tabular}

Sourse: European Commission and International Monetary Fund

*symbol $\mathrm{p}=$ predicted

As seen in the table above, the indicators in the scoreboard manage to reach many of the recommended thresholds as the reference values defined by the MIP.

According to the values recorded by Romania in the case of the current account deficit, we can observe a deterioration of this indicator, which remained below the recommended level within the time frame of the study.

In what regards the net international investment position, it is observed that, during the entire analyzed period, the recorded values exceed the threshold of $-35 \%$ of the GDP. However, this situation is not a real cause for concern, as it is normal for countries like Romania, that are still trying to resolve development gaps with external funding. The net international investment position experienced a steady improvement during the reference period and this was also driven by a growth in the GDP.

The analysis of the cost competitiveness indicators revealed that they had experienced some improvement by 2017, with a slight decrease in the nominal unit labor cost during the period 20112013 , coupled with a depreciation of the real effective exchange rate. The values obtained in 2018, as a result of wage increases, indicate that the level of competitiveness is affected, especially in the public sector, whose labor productivity earnings exceeded the private one. This is supported by the indicators that measure internal imbalances. Therefore, during the reference period, the level of public debt was quite low and recorded a downward path starting with 2016, taking into account the budgetary measures and wage increases that indicate a budgetary relaxation and a pro-cyclical fiscal policy in the period 2016-2018.

Exports registered good results, especially in 2017, which made Romania gain new export market shares. But wage increases in the public sector have put pressure on the private sector, which has led to a decline in cost competitiveness reflected in declining exports in 2018.

The rise in real estate prices has shown a slight reduction in recent years and continues to remain moderate. Credit float towards the private sector accelerated from year to year, which highlights a banking sector that continues to be relatively well capitalized and liquid. A slight downward trend in the debt of the private sector in GDP has manifested in recent years, especially in 2018. This can be determined by the numerous legislative changes, which made the Romanian economic environment unpredictable and contributed to the creation of an unsafe business environment. 
The unemployment rate remained relatively constant during 2011-2015, falling below the benchmark, and the activity rate recorded an upward trend correlated with the context of economic growth. The analysis of employment indicators reveals imbalances in the labor force among young people, highlighting the structural challenges in the labor market.

From the presentation of the indicators of the Macroeconomic Imbalance Procedure Scoreboard, we can observe that the imbalances related to external position and budgetary relaxation are highlighted during 2010-2018. This aspect draws attention to the low level of Romania's economic competitiveness and signals the adverse effects that would be experienced by the national economy if our country's transition to the euro area were to be achieved in this context.

\section{Conclusions}

The current European economic reality is confronted with the paradox. Many of the Member States outside the Eurozone meet the nominal criteria needed to move to the single currency, while some of the countries that have adopted the euro no longer or limitedly meet them.

The existence of disparities between states in terms of the competitiveness gap between their economies and the lack of sustainable convergence and the structural and institutional harmonization between states facilitate the manifestations of internal and external imbalances, which significantly affect the Eurozone. Romania has the opportunity to learn from the lessons experienced by other states that have registered high economic growth rates at the time of the adoption of the single currency, but, after the outbreak of the crisis, the lack of sustainable convergence has led to large losses and significant decreases in their economic growth.

The fact that Romania currently manages to fulfill most of the nominal convergence criteria is not a guarantee that they will have the same trend even in the context of preserving the national currency. The economic and financial crisis has shown that simply fulfilling the nominal criteria is not sufficient for a country to obtain real benefits as a result of entering the Eurozone. The fulfillment of nominal convergence conditions cannot ensure the minimization of the costs of the renouncement to the national currency; therefore our country must guarantee that it can achieve the recommended thresholds for the indicators in the MIP Scoreboard in the medium and long term. Monitoring these early-warning indicators and taking measures to correct them in a timely manner could have helped to avoid internal, external and labor market imbalances and economic shock-induced imbalances.

Considering the repeated postponement of the adoption of the single currency by Romania (2014, 2015, 2019) and the complexity of this process, the arising question is whether 2024, the new date scheduled for this step, is indeed realistic.

It is certain that Romania's accession to the Eurozone under optimum conditions, that guarantee a sustainable integration both for the Romanian economy and for the stability of the European monetary area, presupposes the simultaneous fulfillment of three criteria: a sustainable nominal convergence, the accomplishment of the real and structural convergence criteria and the existence of a more integrated national economy that is compatible with the Eurozone economy.

\section{References}

[1] Daniel Dăianu, Romania and joining the eurozone: the question is, under what conditions, The European Institute of Romania, Bucharest, pp. 22-27, 2016.

[2] Aura Gabriela Socol, The Macroeconomics of European Integration. Case of Romania, Economic Publishing House, Bucharest, pp. 37-40, 2009.

[3] https://ec.europa.eu/eurostat/web/macroeconomic-imbalances-procedure/indicators 